\title{
CLINICAL STUDY TO EVALUATE THE EFFICACY OF YAVAKSHARA PRATISARANA IN THE MANAGEMENT OF TUNDIKERI (CHRONIC TONSILLITIS)
}

\author{
Akshata Narayana Moger ${ }^{1}$, Abhijith $\mathrm{H} \mathrm{N}^{2}$ \\ ${ }^{1} P G$ Scholar, \\ ${ }^{2}$ Associate Professor, Department of Shalakya tantra, Shri Dharmasthala Manjunatheshwara College of \\ Ayurveda and Hospital, Hassan-573201
}

Corresponding Author:Akshata Narayana Moger, PG Scholar, Department of Shalakya tantra Shri Dharmasthala Manjunatheshwara College of Ayurveda and Hospital, Hassan-573201

Article DOI: https://doi.org/10.36713/epra8656

DOI No: 10.36713/epra8656

\begin{abstract}
Introduction: The symptoms of Tundikeri resembles with Chronic Tonsillitis. This disease is more frequent in young and middle aged adults. If not treated in time, chronic tonsillitis may lead to Middle ear infection, Rheumatic fever, Nephritis, Rheumatic heart disease and many other systemic complications. Looking into above facts there is a need of treatment which can prevent complications of the disease as well as reduces the recurrence effectively. In this study an effort has been made to evaluate the efficacy of Yavakshara pratisarana in Tundikeri (Chronic Tonsillitis). Materials and methods: The present study was an open labelled, single arm, clinical study in Tundikeri (Chronic Tonsillitis) ( $n=30)$ selected using convenience sampling technique with pre and post design conducted in a tertiary Ayurveda healthcare centre attached to a teaching institute, situated at the district headquarters in South India. 31 patients fulfilling the inclusion criteria suffering from Tundikeri $w$ s $r$ to Chronic Tonsillitis were selected with the intervention of Yavakshara pratisarana in single sitting.

Results: The effect of therapy was assessed before and after treatment, the results were statistically analyzed; it showed significant changes in subjective parameters like Katina shopha,Mandaruk, Galaragata,Galoparodha ,Halitosis,Enlarged Jugulodigastric lymph nodes, and Objective parameter- ESR

Conclusion: Yavakshara pratisarana has shown better efficacy in subjective parameters likeKatinashopha,Mandaruk,Galaragata,Galoparodha,Halitosis,EnlargedJugulodaigastric lymph nodes , and Objective parameter like- ESR

KEY WORDS: Tundikeri, Yava kshara, Pratisarana.
\end{abstract}

\section{INTRODUCTION}

In Ayurveda, Tundikeri is described under Mukha roga. Acharya Sushrutha has mentioned Tundikeri as Talugata roga and Acharya Vagbhata as Kantagata roga.
Tundikeri presents with the features of Katina shopha (enlargement of tonsils) in Hanusandhi, Manda ruk (pain), Toda (pricking sensation), Daha (burning sensation) and resembles Karpasa phala ${ }^{1,2}$ (fruit of cotton). Mainly caused due to vitiation of Kapha and 


\section{EPRA International Journal of Research and Development (IJRD)}

\section{Raktha dosha ${ }^{3}$}

Tundikeri is commonly encountered now days due to the dietary habits of taking spicy food, cold beverages and cold climate. Lower socio-economical people are particularly prone as the immunity status is low in them. These factors coupled together results in recurrent episodes of the disease.

In modern science Tundikeri can be co-related to Tonsillitis. Tonsillitis is the infection of tonsils, situated on either side of back of throat, which forms vital part of immune system and aids the body in fighting diseases and infections.

Tonsillitis is one of the most common disease of upper respiratory tract which affects all age groups, It is estimated that $15 \%$ patient visit to a family doctor are because of Chronic Tonsillitis ${ }^{4}$. At puberty prevalence rise to 70-90\%. Most common age of Tonsillitis found to be $11-21(56 \%) ; 21-30(20 \%)$; <10(10\%) ; 31$40(9 \%) ; 41-50(3 \%) ; 50(1 \%)^{5}$.

If not treated in time, chronic tonsillitis may lead to Middle ear infection, Rheumatic fever, Nephritis, Rheumatic heart disease and many other systemic complications ${ }^{6}$.

Antibiotics are the main stay of treatment in allopathic medicine which gives temporary relief and does not check the recurrence of disease and sets a platform for Tonsillectomy, which has its own complications.

Looking into above facts there is a need of treatment which can prevent complications of the disease as well as reduces the recurrence effectively.

Many treatment modalities are described in Mukharogas, among them Shastrakarma is said to be the effective one ${ }^{7}$. Kshara is said be Pradhana among shastra and anushastra karmas.

The yavakshara pratisarana was selected from Rasa tarangini for this present clinical trial.This formulation is indicated in all types of Kanthagata Roga in the form of Kavala and Pratisarana ${ }^{8}$ etc.

Pratisarana with Yavakshara mentioned in Rasa tarangini in the management of Tundikeri possess qualities like kaphahara, Vrana shodhaka, ropaka as well as crapping effect, Kapha-Rakta Shamaka, Lekhaka, Shodhaka, Krimihara, Shothahara, etc properties. The Kshara does the Ksharana of localized Vikriti and thus helps in Samprapti Vighatana.

Sushruta opines that the diseases which can be treated with Kavala can also be treated with Pratisarana. Keeping this into consideration, the present study was planned to evaluate the efficacy of yavakshara Pratisarana in the management of
Tundikeri (Chronic Tonsillitis).

\section{AIMS AND OBJECTIVES}

To Evaluate the effect of Yava kshara Pratisarana in Tundikeri.

\section{MATERIALS AND METHODS}

Source of data: The patients will be selected from the out patient and in patient department of Sri Dharmasthala Manjunatheshwara College of Ayurveda and Hospital, Hassan.

Ethical Committee Approval Number SDM/IEC/65/2019

Clinical Trial Registry of India CTRI/2020/11/029371

\section{CRITERIA OF EVALUATION DIAGNOSTIC CRITERIA}

Diagnosis will be made on the basis of any of the 4 symptoms of Tundikeri.

- Kathina Shopha (enlargement of tonsils)

- Manda Ruk (pain)

- Ragata (hyperemia)

- Galoparodha (dysphagia)

- Mukha daurgandhya (Halitosis)

- Enlargement of lympnodes.

\section{INCLUSION CRITERIA}

Age group between 16-50 years

Irrespective of gender, religion, socioeconomic status

- Patients clinically diagnosed with Tundikeri and fit for Ksharakarma.

- Patients ready to sign informed consent form.

- Patient not respond to medical management will be included.

- Parents willing to sign the informed assent form (age group between 16-18 year)

\section{EXCLUSION CRITERIA}

- Patient with Acute tonsillitis, Peritonsillar abscess, Acute otitis media, Tonsilar cyst .

- Uncontrolled Hypertension and Diabetes Mellitus

- Physiological conditions like pregnancy, lactation and puerperal stage.

STUDY DESIGN The present study was an open labeled, single arm, clinical study in Tundikeri (Chronic Tonsillitis) $(\mathrm{n}=30)$ selected using convenience sampling technique with pre and post design conducted in a tertiary Ayurveda healthcare centre attached to a 
teaching institute, situated at the district headquarters in South India

\section{LABORATORY INVESTIGATION}

Following lab investigations will be performed for the diagnosis.

Blood investigations: $\mathrm{ESR}, \mathrm{DC}, \mathrm{TC}, \mathrm{Hb} \%$.

\section{DRUG ADMINISTRATION}

Drug: Yavakshara

Dosage: As required

Duration: single sitting application

\section{ASSESSMENT CRITERIA}

The subjects will be accessed before treatment $\left(0^{\text {th }}\right.$ day), after 24 hours of treatment $\left(1^{\text {st }}\right.$ day) and on eighth day $\left(8^{\text {th }}\right.$ day) and after this subject will be asked to visit the center on $15^{\text {th }}$ and $30^{\text {th }}$ day of treatment to notice any changes if occurred. Assessment table is given at (Table 1)

\section{PARAMETERS}

Both subjective and objective parameters will be assessed.

\section{Subjective parameters}

1. Kathina shopha (Enlargement of tonsils)

2. Manda Ruk (Pain)

3. Ragatwa (Redness)

4. Galoparodha (Dysphagia)

5. Halitosis

6. Jugulo-digastric lymphadenopathy

\section{Objective parameters}

1. Pictoral presentation

2. Investigation

\section{STATISTICAL ANALYSIS}

- Friedman's test was applied to analyze the significance of change in Subjective parameters

- Wilcoxon signed rank test was done as post hoc with Bonferroni correction on parameters whichshow significance in Friedman's test, to interpret the time of significant change

- Paired $T$ test was done for analyzing the significance of objective parameters

\section{OBSERVATION}

In the present study total 42 subjects were screened, out of which 33 subjects were registered for the study, among them 31 subjects completed the study and 2 were dropped out Among 31 completed subjects maximum $(n=15)$ were from the age group of 31-60 years and predominance of females $(n=27)$ over males was found. 14 subjects were from middle class group and majority of them $(n=19)$ were having sedentary life style. Diet wise distribution showed maximum $(n=31)$ were having non veg diet ,14 were habituated to Guru ahara , $(\mathrm{n}=9)$ subjects to Dadi/ksheera, $(\mathrm{n}=7)$ subjects were habituated to cold beverage. Considerable number of subjects $(n=14)$ were having mandagni,$(n=11)$ subject were practicing vishamashana, maximum number of subjects $(n=16)$ were having moderate oral hygeine

\section{RESULTS}

In the present study total 42 subjects were screened, out of which 33 subjects were registered for the study, among them 31 subjects completed the study and 2 were dropped 32 subjects were underwent application of Yavakshara pratisarana in single sitting Friedman's test was run on subjective parameters and has shown significant improvement in symptoms like Katina shopha ,Mandaruk,Galaragata,Galoparodha, Halittois, jugulodaigarstic. Results are placed at (Table 2) Paired t Test was run on objective parameters like HB, TC, DC and ESR. ESR values has shown significant improvements. Results are placed at (Table 3)

\section{DISCUSSION \\ EFFECT OF THERAPY ON SUBJECTIVE PARAMETER \\ Effect on Katina shopha :}

There was significant reduction Katina shopha, Wilcoxon signed rank test as post hoc test with Bonferroni correction - 0.01 also showed reductions in between D1 to D30 ( $\mathrm{p}<0.001)$ The Shopha (Swelling) is due to inflammatory process in tonsils. When the inflammatory process begins in the tonsillar tissue, it becomes swollen and causes the symptoms like pain in throat, difficulty in deglutition (dysphagia).

Vitiation of kapha and rakta invariably involved in the pathogenesis of Tundikeri will bring about inflammatory changes, due to which there will be pain in the throat. Intensity of pain depends upon extent of inflammation.

This might be due to two reasons. Viz. -

- The antibacterial and anti-inflammatory action of the drug clears the infective

focus. Thus, the tonsillar tissues might have relieved from inflammatory symptoms. Kapha -pitta hara and Shotha hara property of yava 
brings down the inflammation and also by analgesic effect of yava reduces the intensity of pain.

- The overall property of the formulation is Kshareeya in nature. It is responsible for Chhedana, Bhedana, Lekhana karma in the tonsillar tissue. Though the medication is applied over the surface of the tonsils it penetrates in to the crypts and core of tonsillar tissue by means of its Sukshma, Teekshna, Vyavayi properties. The drug also acts as an agent for chemical cauterization by which causes the atrophy of inflamed tonsillar tissue.

\section{Effect on manda ruk}

- There was significant reduction in manda ruk, Wilcoxon signed rank test as post hoc test with Bonferroni correction - 0.01 also showed reductions in between D1 to D30 (p < $0.001)$ Vitiation of kapha and rakta invariably involved in the pathogenesis of Tundikeri will bring about inflammatory changes, due to which there will be pain in the throat. Intensity of pain depends upon extent of inflammation.

- Kapha-pitta hara and Shothahara property of Yavakshara brings down the inflammation and also by analgesic effect of Yava reduces the intensity of pain.

\section{Effect on Galaragata}

- There was significant reduction in Galaragata, Wilcoxon signed rank test as post hoc test with Bonferroni correction - 0.01 also showed reductions in between D1 to D30 ( $p<$ 0.001 )

The change in colour of mucus membrane is due to the inflammatory process in the tonsillar tissues. Ragatwa is assessed on changes in colour of muco-lymphoid tissues. The change in colour of mucus membrane varies as per changing pattern of vascularity The probable reason might be the action of medication till the core of tonsillar tissue which subside the disease through its invaded area. The trial drug due to its antiinflammatory, analgesic action reduces the inflammation and hence colour of the mucus membrane becomes normal.

\section{Effect on Galoparodha}

- There was significant reduction in Galoparodha, Wilcoxon signed rank test as post hoc test with Bonferroni correction - 0.01 also showed reductions in between D1 to D30 $(\mathrm{p}<0.001)$

Dysphagia is due to inflammatory process and increase in the size of the tonsils and surrounding areas. The inflammatory process in tonsils causes pain in throat. The pain felt by the patient was assessed on the basis of extent and its appearance like mild tolerable pain during deglutition of food articles, liquids.

The intensity, appearance and nature of pain changes as the inflammatory process come down. The anti-inflammatory and analgesic action of the drug property of drug reduces pain on deglutition.

\section{Effect on size of lymph node}

- There was significant reduction in size of lymph node, Wilcoxon signed rank test as post hoc test with Bonferroni correction - 0.01 also showed reductions in between D1 to D30 ( $p<$ 0.001)

The Jugulo-digastric lymphadenopathy is a clinical feature predominantly in chronic tonsillitis with minimal pain and hypertrophy. The reduction in inflammation, signs and symptoms of tonsils result in reduction in size of lymph nodes.

\section{Effect on Mukhadourgandya}

- There was significant reduction in Mukhadourgandya, Wilcoxon signed rank test as post hoc test with Bonferroni correction 0.01 also showed reductions in between D1 to D30 ( $\mathrm{p}<0.001)$ Though, halitosis is not mentioned in classics as a clinical feature, it is found in clinical practice and literature of contemporary sciences. Halitosis is one of the features observed in chronic tonsillitis, pharyngitis or Pharyngo-tonsillitis. Apart from this there are several other causes which cause systemic conditions which causes halitosis like poor digestive power, coated tongue. The probable reason can be taken as the medication acts as (Vaktra shodhana), by acting upon the accumulated Vikrita Kapha causing Halitosis and as infection reduceses complaint of Halitosis will be reduced 


\section{EFFECT OF THERAPY ON OBJECTIVE PARAMETER}

Analysis of change in the Hemoglobin concentration BT and AT had insignificant changes in the Hemoglobin percentage which implied that treatment was ineffective in increasing the Hemoglobin concentration of tonsillitis patients of the study.

Trial drug was effective in the reduction of ESR after treatment $(\mathrm{p}<0.05)$. Statistically significant reduction of these parameters implies the control of the infection

Pictorial presentation - significant change when compared with before and after the treatment (Fig number -01)

\section{Probable mode of action of Yavakshara}

- The Yavakshara possess qualities like lekhana, shothahara, and kapha-raktha hara.

- Yavakshara is shothahara, vedanahara, amapachaka and by its lekhana guna it scrapes the vitiated kapha dosha.It possess the Ksharana and Shodana quality which reduces the obstructive lesions in throat.and helps in reducing the pain and does dosha shamana.

- shothahara by which it helps to reduce the inflammation of the tonsils and also its antibacterial property reduces the infective condition.

- has the property of shulaprashamana, krimighna, jwaraghna, and deepana, which reduces the inflammatory changes in the oral mucosa and tonsils..

1.Ksharana - This property helps in Ksharana of Vikrita Kapha and Mala accumulated in oral cavity, and alleviates the halitosis and thus helps in reducing the symptoms.

The Kshrana effect of medication could have removed the debris and wastes from surface of tonsils as well as deposited elsewhere in oral cavity

The patients Parenchymatous tonsilittis responded well due to Ksharana property of the formulation.

2. Anti-biotics - Different phytochemicals, high percentage of low polar compounds, and various amino acids like histidine ,tryphtophan etc helps in arresting the further growth of bacteria and inflammatory processes. This also prevents the complications of the diseases.

3.Antimicrobial - The formulation contains lysine bitter principles, which acts as antimicrobial agent and reduces the growth of micro organisms like bacteria and viruses.

4. Analgesics - Once inflammation subsides by pratisarana, pain reduceses and also this formulation possess analgesic property which helps in alleviating the pain.

\section{PROBABLE MODE OF ACTION OF PRATISARANA}

The word meaning of Pratisarana is Gharshana or rubbing. In present clinical study the Pratisarana of Yavakshara is performed over the tonsils. Its probable mode of action can be assumed as follows - Action of Lignox $10 \%$ -

It is a local anaesthetic agent, used to desensitize the mucosa of the oro-pharynx and palate temporarily. This prevents the gag reflex, pain of procedure and irritation due to medications. This facilitates the convenience of the procedure even in non-cooperative patients. With in 1 to 2 two hours of procedure patient regains the sensation and gustatory perception.

\section{Action of cotton ball rubbing over the anterior surface of tonsils -}

The gentle rubbing of the cotton over the tonsils in case of follicular tonsillitis, ruptures the follicles and opens the crypts. It removes the sticky thick mucosal coating from the anterior surface of tonsils and facilitates the direct contact of tonsil tissue with the medication. This facilitates easy penetration of the medicine into crypts to reach the action of medication till core of tonsils.

\section{Action of the medication over the tonsillar tissue -}

explains that Rasa acts when it comes in contact with mouth,vipaka acts after digestion and virya acts at the both level internally and externally.Hence for mode of action of pratisarana drug, we have to rely on Rasa and Virya of drug.Due to Laghu ruksha guna subsides kapha dosha,ushna virya both vata and kapha,Due to Ushna virya, and laghu ,Ruksha guna,it stimulates agni and due to its ushna virya,teekshna,laghu guna removes Srothorodha and vitiation of Rakta dhatu is normalized by katu ,madhura rasa properties of drugs

The medication contains the Kshareeya dravya and lekhana property, (it corrodes the hypertrophied muscle tissue)which acts as a chemical cauterizing agent over the tonsillar tissues. By the local application of Kshara it reduces the Vikrita Kapha. Due to Cchedana, Bhedana action of Kshara, it reduces the 
size of tonsils significantly.due to its Ruksha Guna ,it has Kledahara property.Due to Katu Rasa ,it causes "Shonita Sanghatam Bhinnatti" (clears the obstruction in Raktavaha strothas)

The alkaline medication entered into core of tonsils cause chemical cauterization. Due to Cchedana, Bhedana, Ushna, Teekshna properties forms minute burns and there is a coagulation of muco-lymphoid tissues. This reduces the intracellular space and aggregates the lymphoid tissues. This intern stimulates fibrosis of tonsillar tissue and reduces the size of the tonsils.

\section{CONCLUSION}

1) The study drug, Yavakshara pratisarana is effective in reducing the majority of signs and symptoms of Chronic Tonsillitis.

2) Yavakshara pratisarana is effective in reducing the number of attacks of Chronic Tonsillitis.

3) Yavakshara pratisarana has provided sustained effect.

Financial Support and sponsorship: Nil

Conflicts of interest: There are no conflicts of interest

\section{REFERENCES}

1. Astanga hrudaya of vagbhata, with commentaries sarvangasundari of arunadatta and Ayurveda rasayana of hemadari, edited by bhisagacharya Hari sadashiva sastri paradakara, chowkhamba surbharati prakashan Varanasi, Edition-2010, uttarasthana 21 st chapter, 47 th verse.

2. Sushrutha Samhita of susruta, with the Nibandhasangraha commentary of sri dalhanacharya and the Nyaya Chandrika of sri gayadasacharya on nidanasthana, edited by Vaidya yadavji trikamji Acharya and Narayan ram Acharya kavyatirtha, chaukambha Sanskrit sansthana, Varanasi, Edition-2012, Nidhanasthana, 16th chapter, 42 verse.

3. Bhavaprakasha of Bhava Mishra(vol-2) Uttara and madhyama khanda, Translated by Prof.K.R. Srikantha Murthy.Edition-2009, 66th chapter, 100th verse.

4. G.P Arun raj,U Shailaja ,N Prasanna Rao.Chronic tonsillitis in children :An Ayurvedic Bird View.IAMJ[Internet];2013 AUG :Volume VOL 1 (4).Available form: http://www.iamj.in/images/upload/IAMJ12.pdf

5. Sarode D $S$, Bhole A $V$.Prevalence of chronic tonsillitis at ENT inpatient department: a hospital based study.IJM(internet).2015 Nov 23 vol 2(11);p 788.

6. Diseases of Ear, Nose and Throat and head and neck surgery by PL Dhingra, 6th edition.

7. Vagbhata,Arunadatta,Hemadri,Uttarasthana chapter 22 Mukharoga pratishedam verse 56.In;Shastri Hari Sadashiva (edi.). Astangahrudaya with Sarvangasundara and Ayurvedarasayana commentaries. Reprint 2011edition. pune: Chaukambha Sanskrit Sansthan; 2011: p. 528

8. Pranacharya Sadanandasharma, Shree Haridatta Acharya,Acharya Dharmanandashastri.Ksharatrika Vijnaniya trayodasha Taranga Chapter 13verse 6. In : Kashinath Shastri(edi.) Rasatarngini, 2014 edition. Varanasi: Motilala Banarasidas; 2014: p308.

9. Sushruta. Sushruta Samhita edited with Ayurveda Tattva Sandipika commentary. Edited by Kaviraj Ambikadutta Shastri. $13^{\text {th }}$ Edition 2002. Chikitsasthana $40^{\text {th }}$ Chapter $71^{\text {th }}$ Shloka. Varanasi: Chaukhamba Sanskrita Samsthana. p.186s

Table: 1 Self formulated Scale for assessment of Subjective parameters

\begin{tabular}{|c|c|c|c|c|c|c|}
\hline $\begin{array}{l}\text { SI } \\
\text { NO }\end{array}$ & $\begin{array}{c}\text { Assessment } \\
\text { criteria }\end{array}$ & 0 & 1 & 2 & 3 & 4 \\
\hline 1. & $\begin{array}{l}\text { Size of Tonsil } \\
\text { (Khatina shopha) }\end{array}$ & $\begin{array}{l}\text { No tonsils } \\
\text { seen }\end{array}$ & $\begin{array}{l}\text { Small tonsils } \\
\text { within the } \\
\text { tonsillar fossa. }\end{array}$ & $\begin{array}{l}\text { Visible } \\
\text { beyond } \\
\text { anterior } \\
\text { pillars. }\end{array}$ & $\begin{array}{c}\text { Extended } 3 / 4^{\text {th }} \\
\text { of way to } \\
\text { midline. }\end{array}$ & $\begin{array}{c}\text { Completely } \\
\text { obstructing } \\
\text { airway.(kissing } \\
\text { tonsils) }\end{array}$ \\
\hline 2. & $\begin{array}{l}\text { Mandaruk } \\
\text { (pain) }\end{array}$ & No pain & $\begin{array}{l}\text { Pain on } \\
\text { external } \\
\text { pressure }\end{array}$ & $\begin{array}{c}\text { Pain during } \\
\text { deglutition } \\
\text { and relieves } \\
\text { thereafter }\end{array}$ & $\begin{array}{c}\text { Pain increases } \\
\text { on deglutition } \\
\text { and remains } \\
\text { Consistent }\end{array}$ & \\
\hline 3. & $\begin{array}{c}\text { Galaragata } \\
\text { (Hyperaemia) }\end{array}$ & $\begin{array}{c}\text { No } \\
\text { hyperaemia }\end{array}$ & $\begin{array}{l}\text { Hyperaemia of } \\
\text { tonsil surface. }\end{array}$ & $\begin{array}{c}\text { Pinkish } \\
\text { appearance of } \\
\text { Pillars }\end{array}$ & $\begin{array}{c}\text { Reddish } \\
\text { appearance of } \\
\text { surrounding }\end{array}$ & $\begin{array}{l}\text { Reddish } \\
\text { appearance of } \\
\text { pharynx }\end{array}$ \\
\hline 4. & $\begin{array}{l}\text { Galoparodha } \\
\text { (Dysphagia) }\end{array}$ & $\begin{array}{c}\text { No pain } \\
\text { while } \\
\text { swallowing }\end{array}$ & $\begin{array}{c}\text { Pain during } \\
\text { swallowing } \\
\text { solid food }\end{array}$ & $\begin{array}{l}\text { Pain during } \\
\text { swallowing } \\
\text { solid food }\end{array}$ & $\begin{array}{c}\text { Pain during } \\
\text { consuming } \\
\text { liquid food }\end{array}$ & $\begin{array}{l}\text { Continuous pain } \\
\text { or unable to } \\
\text { swallow. }\end{array}$ \\
\hline
\end{tabular}




\section{EPRA International Journal of Research and Development (IJRD)}

Volume: 6 | Issue: 10 | October 2021

- Peer Reviewed Journal

\begin{tabular}{|c|c|c|c|c|c|c|}
\hline & & & substance. & substance. & substance. & \\
\hline 5. & $\begin{array}{l}\text { Mukhadourgandya } \\
\text { (Halitosis) }\end{array}$ & No halitosis & $\begin{array}{l}\text { Foul breath } \\
\text { experienced by } \\
\text { patient only. }\end{array}$ & $\begin{array}{l}\text { Foul breathe } \\
\text { experienced by } \\
\text { patient } \& \\
\text { friends or } \\
\text { parents. }\end{array}$ & $\begin{array}{l}\text { Foul breathe } \\
\text { experienced by } \\
\text { a group of } \\
\text { surrounding } \\
\text { people. }\end{array}$ & $\begin{array}{c}\text { Foulbreath } \\
\text { experienceby as } \\
\text { soon as the patient } \\
\text { opens the mouth. }\end{array}$ \\
\hline 6. & $\begin{array}{l}\text { Enlargement of } \\
\text { lymph nodes }\end{array}$ & $\begin{array}{l}\text { No palpable } \\
\text { lymph nodes. }\end{array}$ & $\begin{array}{l}\text { Palpable lymph } \\
\text { node U/L } \\
\text {,warm }\end{array}$ & $\begin{array}{l}\text { Palpable lymph } \\
\text { nodes B/L, soft } \\
\text { fluctuant. }\end{array}$ & $\begin{array}{c}\text { Palpable lymph } \\
\text { nodes B/L } \\
\text { which are hard }\end{array}$ & $\begin{array}{c}\text { Palpable lymph } \\
\text { nodes B/L which } \\
\text { are hard }\end{array}$ \\
\hline
\end{tabular}

Table: 2 Showing effect of yavakshara pratisarana on subjective parameters by applying Friedman's test

\begin{tabular}{|c|c|c|c|c|c|}
\hline Parameters & $\mathbf{N}$ & Mean Rank & $\begin{array}{c}\text { Chi Square } \\
(\mathbf{x} 2) \\
\end{array}$ & p value & Remarks \\
\hline Katina shopha BT & \multirow{5}{*}{31} & 4.39 & \multirow{5}{*}{101.249} & \multirow{5}{*}{$<0.001$} & \multirow{5}{*}{ Significant } \\
\hline Katina shopha $1^{\text {st }}$ DAY & & 4.19 & & & \\
\hline Katina shopha $8^{\text {th }}$ DAY & & 2.37 & & & \\
\hline Katina shopha $15^{\text {th }}$ DAY & & 2.05 & & & \\
\hline Katina shopha $30^{\text {th }}$ DAY & & 2.00 & & & \\
\hline Mandaruk BT & \multirow{5}{*}{31} & 4.79 & \multirow{5}{*}{109.873} & \multirow{5}{*}{$<0.001$} & \multirow{5}{*}{ Significant } \\
\hline Mandaruk $1^{\text {st }}$ DAY & & 3.92 & & & \\
\hline Mandaruk $8^{\text {th }}$ DAY & & 2.15 & & & \\
\hline Mandaruk $15^{\text {th }}$ DAY & & 2.10 & & & \\
\hline Mandaruk $30^{\text {th }}$ DAY & & 2.05 & & & \\
\hline Galaragtva BT & \multirow{5}{*}{31} & 4.74 & \multirow{5}{*}{111.360} & \multirow{5}{*}{$<0.001$} & \multirow{5}{*}{ Significant } \\
\hline Galaragtva $1^{\text {st }}$ DAY & & 4.13 & & & \\
\hline Galaragtva $8^{\text {th }}$ DAY & & 2.39 & & & \\
\hline Galaragtva $15^{\text {th }} \mathrm{DAY}$ & & 1.94 & & & \\
\hline Galaragtva $30^{\text {th }} \mathrm{DAY}$ & & 1.81 & & & \\
\hline Galoparodha BT & \multirow{5}{*}{31} & 4.73 & \multirow{5}{*}{102.771} & \multirow{5}{*}{$<0.001$} & \multirow{5}{*}{ Significan } \\
\hline Galoparodha $1^{\text {st }} \mathrm{DAY}$ & & 3.82 & & & \\
\hline Galoparodha $8^{\text {th }}$ DAY & & 2.23 & & & \\
\hline Galoparodha $15^{\text {th }}$ DAY & & 2.11 & & & \\
\hline Galoparodha $30^{\text {th }}$ DAY & & 2.11 & & & \\
\hline $\begin{array}{l}\text { Jugulo-digastric } \\
\text { lymphadenopathy BT }\end{array}$ & \multirow{5}{*}{31} & 4.63 & \multirow{5}{*}{100.602} & \multirow{5}{*}{$<0.001$} & \multirow{5}{*}{ Significan } \\
\hline $\begin{array}{l}\text { Jugulo-digastric } \\
\text { lymphadenopathy } 1^{\text {st }} \text { DAY }\end{array}$ & & 3.94 & & & \\
\hline $\begin{array}{l}\text { Jugulo-digastric } \\
\text { lyphaadenopathy } 8^{\text {th }} \text { DAY }\end{array}$ & & 2.40 & & & \\
\hline $\begin{array}{l}\text { Jugulo-digastric } \\
\text { lymphadenopathy } 15^{\text {th }} \text { DAY }\end{array}$ & & 2.05 & & & \\
\hline $\begin{array}{l}\text { Jugulo-digastric } \\
\text { lymphadenopathy } 30^{\text {th }} \mathrm{DAY}\end{array}$ & & 1.98 & & & \\
\hline
\end{tabular}




\section{EPRA International Journal of Research and Development (IJRD)}

Volume: 6 | Issue: 10 | October 2021

- Peer Reviewed Journal

Table: 3 Showing effect of Yavakshara pratisarana on Objective parameters by applying Paired t Test

\begin{tabular}{|c|c|c|c|c|c|c|c|c|}
\hline \multirow{2}{*}{ Parameter } & \multicolumn{2}{|c|}{ Mean } & \multicolumn{7}{c|}{ Paired Difference } & \\
\cline { 2 - 9 } & BT \pm SD & AT \pm SD & $\begin{array}{c}\text { Mean } \\
\text { Difference }\end{array}$ & SD & SE & $\begin{array}{c}\text { ' } t \text { ' } \\
\text { value }\end{array}$ & 'P'value & Remark \\
\hline ESR & 8.958 & 5.661 & 12.910 & 7.472 & 1.342 & 9.620 & .000 & S \\
\hline TC & 2277.671 & 1308.278 & -93.548 & 1992.475 & 357.859 & -.261 & .796 & NS \\
\hline HB & 1.522 & 1.249 & -.110 & .110 & .190 & -.579 & .567 & NS \\
\hline
\end{tabular}

Fig no -01

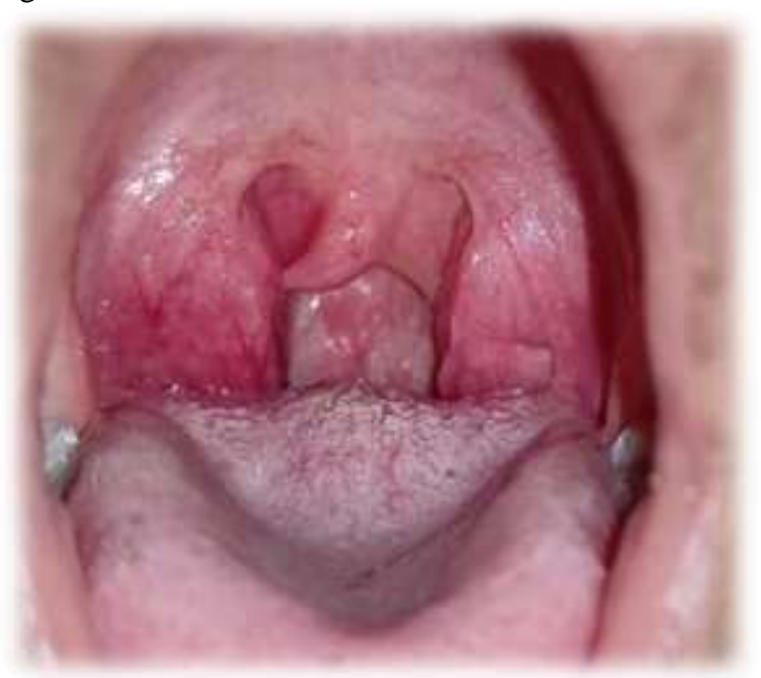

Fig No : 05 Before treatment on $0^{\text {th }}$ day

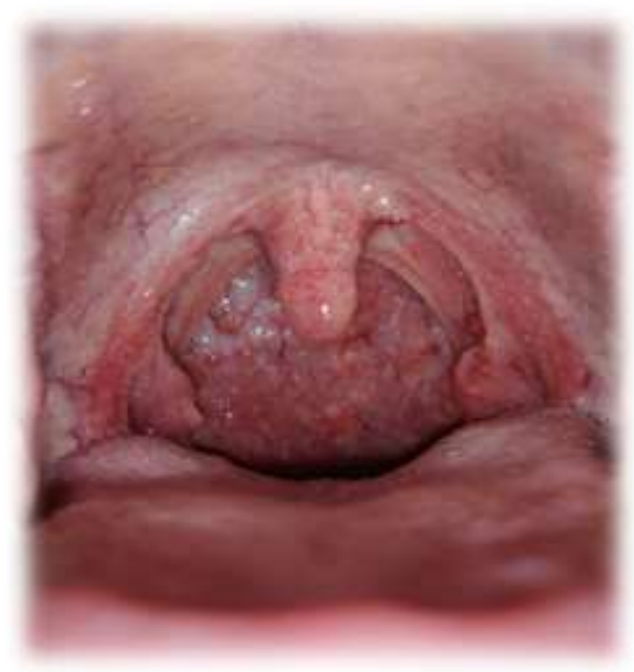

Fig No: 06 After treatment on $30^{\text {th }}$ day 